\title{
PHILOSOPHICAL ISSUES OF THE FIGHT AGAINST CORRUPTION IN GOVERNMENT AND SOCIETY
}

\author{
Isomiddinov Yunusjon Yusubboevich \\ Researcher of Samarkand State Institute of Foreign Languages, \\ Samarkand, Uzbekistan
}

\begin{abstract}
Corruption is an invisible disease of society, which has little impact on the socioeconomic and political life of any country and is a flaw that hinders the development of an entire country. This article reveals the current aspects of the fight against corruption in the construction and management of the state and society. Legislative programs to combat corruption and the work being done in this area are also discussed in detail. The fact that the legislation of the Republic of Uzbekistan reflects and gradually develops measures to combat corruption is also based on the facts.
\end{abstract}

Key words: corruption, state, and society, constitution, Islam, Anti-Corruption Law, Convention on Criminal Liability for Corruption.

Cite this Article: Isomiddinov Yunusjon Yusubboevich, Philosophical Issues of the Fight against Corruption in Government and Society, International Journal of Management, 11(12), 2020, pp. 1035-1043.

http://iaeme.com/Home/issue/IJM?Volume=11\&Issue=12

\section{INTRODUCTION}

In the history of human society, every state has tried to prevent various forms of moral threats and corruption in society in order to increase its power. The prevention of factors that negatively affect the development of such a state and society, the involvement of people in the social life on the basis of transparent and democratic reforms is an important philosophical process. To this end, the formation of ideological immunity in the minds of every citizen in society to prevent corruption is an urgent philosophical issue. The formation and development of the ideological immunity of citizens against corruption in society is a direct goal of a just, democratic state. A person working to build a just civil society that respects universal values, based on the national mentality of other nations and peoples living in Uzbekistan today, will have a philosophical outlook on foreign ideologies and views in society.

As noted by President Sh.M.Mirziyoev, "We will mobilize all our forces and capabilities to establish in our society the principle of "Law and justice - priority, punishment for a crime - inevitable". It should be noted that among the noteworthy work in this direction is the 
creation of an integrated system of combating corruption. "The adoption of the Law on Combating Corruption has made it possible to combine the efforts and capabilities of the state apparatus and civil society institutions in the fight against this dangerous scourge." [1] Legal reforms are being carried out in educational institutions, mahallas, and organizations to combat negative vices in all spheres of society, especially to reduce corruption. This propaganda is directly aimed at strengthening the people's confidence in the ideology that exists in society, ensuring that the interests of man take precedence over all else and that the people live a clean and honest life.

The fight against corruption in public administration and society has been focused on the individual and his interests as a priority. The criteria of combating corruption are reflected in the national mentality, as a conscious being, intelligent, perceptive behavior, aesthetic ideals, behavior, lifestyle, behavior, ethics, manners, customs. Such an ideological and spiritual process, in turn, is the main criterion of a just system in the formation of each young generation as a person, regardless of nationality, race, lineage, religion, belief. Because a just and prosperous social life is a spiritual need not only for a nation or country but also for humanity. The main task of all of us is to encourage such an individual to connect with the destiny of the nation, the destiny of the nation with the destiny of mankind, and to bring up such young people. Speaking about this, Sh.M.Mirziyoev said, "Considering that more than half of the population of our country are young people, it becomes even clearer how serious this issue is.

At this point, I would like to briefly dwell on the tasks related to strengthening ideological immunity in the hearts and minds of our children. First of all, we must never forget that each of us is responsible for protecting our youth from the various threats that come in the form of "mass culture", such as drug addiction, religious extremism, missionary work. In this regard, we rely on the national traditions formed over the centuries, the rich spiritual heritage of our ancestors. "[2] Therefore, in a country where a new national ideology has been formed and is stable, a new culture of youth based on openness and transparency, an attitude in line with universal intellectual values will be formed and developed. This process is an objective necessity arising from the content and essence of building a humane, just society without various corruption mechanisms.

\section{MAIN PART}

If a state or society is limited to the development of a specific legal system in its territory and ignores the role and place of other peoples and nations in human civilization, then humanity, humanity, the future of humanity, independence, cooperation, Signs such as friendship, brotherhood, etc. are made through corruption, and as a result, the social system may face a crisis.

We must not forget that at a time when ideological conflicts, threats, and corruption chains are intensifying around the world, it is important to develop the law in our country to reduce the impact of this threat on public administration. We believe that the national ideology is one of the most important factors in the development of our country, and therefore we are fighting through the law to establish inter-ethnic relations in our society. All of us must use the examples of our high spiritual heritage wisely and enrich the solid base of our national ideology so that every person in the society can live in harmony and harmony.

The main task of the society is to live with the joy of the Motherland, its joys and sorrows, to be brave in the face of adversity, to protect the future of our country, the freedom of our people, to protect its security. We must fight and develop our non-discriminatory entrepreneurship on the basis of our national ideology. At the same time, when we say entrepreneurs, we do not mean "super-rich people who have amassed innumerable wealth 
through various dirty, corrupt ways, as in some neighboring countries, but millions of our entrepreneurs and businessmen who earn money through their honest work, intelligence, and energy." [3].

Today, the formation and development of legal consciousness and national mentality is an urgent issue in society to get rid of the negative flaws in the fight against corruption. We need to develop in citizens such ideas as national pride, a sense of pride, creativity, courage, love for the Fatherland, and confidence in the future, which fight against the scourge of corruption.

In the current process of combating corruption in Uzbekistan, the main focus is on educating the younger generation and ensuring justice in this process. On the basis of local reforms, first of all, attention is paid to the fate of the Motherland, the future of the nation, building a free and prosperous homeland, educating a generation with modern knowledge and thinking, improving every region of the country and enriching the aesthetic world of a spiritually mature person. As we strive to create a corruption-free society in our country, we must all understand the essence of the decisions and laws that are being made, and make our young people aware of the need to contribute to these changes. Otherwise, we will lose our many achievements in society. "In the face of certain difficulties of the transition period, it may be formed and decided in the minds of citizens, especially in the younger generation, that the main way to achieve a high standard of living is through illegal activities. The pursuit of wealth in a devious way, if left unchecked by society and legal control, can lead people astray, especially young people who are just starting out in life. After all, what could be more tragic and devastating for society and the state than the moral depravity and apathy of the younger generation?" [4]. So, in any case, for the development of society and its development, it is important to be free from various ideological attacks, to create in the minds of young people an aesthetic education that is in harmony with the modern world.

In the ideology of any society, it is characterized by its rarest and most unique virtues, namely, kindness, patience, thoughtfulness, modesty, modesty, delicacy, sharpness, modesty, tolerance, diligence, humanity and other spiritual values. the intertwined ideas will be embodied. On this basis, it is possible to create some kind of national ideology in society on the basis of the interrelation of certain national ideas with each other as a system. The reason for this is that although the national idea is the basis of the national ideology, it consists of ideas as a specific system. For this national ideology to emerge, it must be composed of certain national ideas and be shaped as a system that influences the individual's worldview. But it is necessary to eliminate the elements of corruption, to express the aspirations of the people.

First, in the fight against corruption, it is necessary to strengthen public confidence in the national ideology, to develop in every citizen a sense of honesty and purity in connection with the history of our people. The national ideology of our ancestors as a philosophical manifestation in social life has played an important role in the practical and spiritual life of society. In this ideological process, it is important for our people to have faith in Allah and respect the beautiful scenery of nature. It calls people to live a just life in the way of Allah, to refrain from negative vices by calling them to purification. Only a certain system of great ideas can fulfill the task of influencing the psyche of an individual through belief in Allah in social life, reaching the heart of each person, motivating them to great and unique goals. This situation can be likened to the fact that nature also shows people its beauty and influences them with colors arranged in a certain order, rather than with a single color so that people can enjoy it.

Second, Islam is recognized today as the most perfect religion in the world. This is what has emerged in society as a propagandist of our ideology. It promotes ideological views on the prevention of corruption in people. Religion, based on the goals and interests, needs and 
aspirations of the people, encourages man to work for goodness and creativity, to unite and mobilize great goals. It serves to be honest and humble on the basis of the system of thousands of ideas set forth in the Qur'an and Hadith. Therefore, in the propaganda of national ideology, religion emerges, first of all, as an ideological system, activating not only a system consisting of many national and non-national ideas but also a system of specific actions.

Third, national ideology plays the role of ideological prevention in the fight against corruption in society. At the same time, the national ideology will have such new potential that its influence on the people will increase several times. Because every national idea in it has a deeper and clearer understanding. It is based on the principles of the national idea.

In addition, secular knowledge, religious and divine values, enlightenment, philosophical observations about the perfect man, wisdom, freedom, justice, purity, honesty, courage, patriotism, humanity, sophistication, the essence of man, the meaning of human life, how to reduce corruption in our society. etc., wise ideas about national and universal moral and aesthetic views, fairy tales and legends reflected in the healthy lifestyle, thinking and worldview of our people, the lives of our national heroes, educating with ramona works, and so on is an important goal of our national ideology. In this regard, President Sh.M.Mirziyoev said, "In order to effectively combat corruption in our country, a special law has been adopted in this area. On this basis, the state program, which includes measures aimed at specific goals, is being consistently implemented. As a result of such work, in the first 9 months of this year, corruption-related crimes decreased by $33 \%$ compared to last year. We must accept such results as the first result of our long and lasting work in the fight against corruption, and we must work harder in this direction "[5].

As long as the national ideology serves to fight corruption in society, it can never function as a state ideology. It should be based only on the worldview of the people. Because in this regard, the Constitution of the Republic of Uzbekistan states that "social life in the Republic of Uzbekistan develops on the basis of diversity of political institutions, ideologies, and opinions.

No ideology can be established as a state ideology. "[6] We all need to understand that these sentences are not the ideology of the state in which we fight corruption, but the ideology of our people aimed at shaping the honest and clean life of every person in our society. On the basis of national ideology, the past and present of our people should be united, their confidence and feel for the future should develop in the hearts of every person as a belief in prosperity and well-being.

The First President of the Republic of Uzbekistan I.Karimov also noted that the ideologies operating in Uzbekistan can never rise to the level of state ideology, "No ideology can rise to the level of state ideology. This constitutional provision imposes on us the task of creating an ideology of national independence. "[7]

The national ideology must embody the social environment of the individual, that is, the national and universal, past and present, religious and secular aspirations that reflect his existence. Such aspects of national ideology play an important role in freeing society from corruption. Speaking about the essence of the national ideology in the formation of this process, the famous philosopher S. Mamashokirov said, "When ideology is popularized in society, ideas emerge, self-regulate, a dynamic system of potentially developing a social environment and the conditions that move it - a living system." will be. "[8] On the basis of this view, the culture of the individual develops on the basis of the dialectic of nationalism and universality, creating the dynamics of the forces driving society through cultural and spiritual culture. In it, the needs, goals, and objectives of the people, material and spiritual heritage, theoretical and practical activities are integrated with the philosophical worldview 
embedded in the spirit of the people. In this way, it becomes a philosophical study that ideology is a necessary and universal process for the social environment of society.

F.Musaev acknowledges the importance of national ideology for the development of society, its renewal in the development of society, and its harmony with the spirit of the times: arises "[9]. Therefore, the national ideology in society should play a laxative role in the fight against corruption.

It is a pressing social issue in society to develop the aspirations of every citizen for the future on the basis of national ideology. A person achieves the goals he has set for himself only when he has a strong belief or belief in a certain field. Society must also be able to convince citizens of its ideas and views in order to build a prosperous future tomorrow. Today, we also need to nurture strong-willed citizens who can unite all people on the path to prosperity and well-being of our country. Only then will we be able to think more broadly and more productively about the fight against corruption in the society we are talking about. In any society, "a person of faith, first of all, does useful work, does not harm others, does not lie. He always keeps his word, that is, when he decides to do something, he mobilizes all his strength and talent, he will do it, he will finish what he started. A believer knows very well what he is doing, why he is doing exactly that. Therefore, a true believer strives for knowledge, lives with a clear goal in mind, strives for perfection in all respects, acquaintance with the good, the desire for greatness becomes his life motto. A true believer wants to leave something for himself, his family, his children, his humanity. Therefore, faith is associated with such qualities as courage, bravery, devotion, will, conscience, determination, honesty, humanity, and patriotism. "[10]

Our national ideology, which reflects a new worldview and the spirit of the times in society, is aimed at building a just state, embodying the spiritual image of the time. The process of social development nurtures people who have a unique and appropriate modern thinking for each period, and who bring about the development of society on the basis of a new worldview. In this process, the philosophical worldview, which raises the prospects of the people, serves to prevent corruption and paves the way for the formation of a national ideology that has a unique image in the path of the nation's destiny, prosperity, peace, and prosperity of the people. The social relations between the individual and the state, the approach to reality from the point of view of justice, the call of people to high spirituality should play a key role as its driving force. In such a situation, each of us felt the need for a society without corruption, aimed at the formation of pure feelings of the individual in society, serving humanity, raising the fate of our people to a higher level.

Today, the development of society and the pursuit of the well-being of the individual, which embodies the age-old aspirations of our people, has led to the emergence of a need for national ideology and its importance at the level of public policy. Emphasizing the urgency of this issue, the head of state said, "Today the times are changing rapidly. Life demands from all of us bold actions, active initiatives, fair and just attitude in all areas. Our people, who have seen a lot, are patient, hardworking, and noble, are waiting for the results of such important changes. He believes that the realization of the noble aspirations of our people, the courage to overcome various obstacles, bureaucracy, indifference, greed, corruption, and the formation of an uncompromising public opinion against them is his profession, the meaning of his life. [11] Staff training is a topical issue of our national ideology.

\section{RESULT AND DISCUSSION}

On the basis of this ideology, it is important to prioritize the interests of the individual in the civil society being built in Uzbekistan, to strengthen the system of "corruption-free sphere" in the activities of the state in the process of reforms. According to the laws of social 
development, "the individual's ideas and ideology and culture are crucial in society" [12]. In this activity, the society's need for high-spirited and fair citizens is growing. This, in turn, requires the strong formation of ideology in all spheres of social life, directing people, who are becoming the driving force of society, towards noble goals. The result is an ideology that reflects the way of life of the people, a common-sense person, or a set of specific views and opinions that nurture the younger generation. This ideology inspires people to great heights on the basis of moral ideals and always serves as a force for spiritual processes.

The national ideology of each society has not only expressed the ideas of a period but has been formed in the worldview of people for thousands of years and manifested itself in the material and spiritual heritage passed down from ancestors to generations. In particular, the national ideology of the Uzbek people, long before the creation of the Avesta, developed the worldview of individuals in public life. Because this ideology has called the people to the highest noble and creative deeds and called them to do all kinds of heroic deeds for the wellbeing of a high-spirited society, as well as for the well-being of the people. Today, Uzbekistan has joined the existing conventions on combating corruption in the world, and in cooperation with the community, the national ideology operates on the basis of our state.

Such a spiritual and social process directly contributes to the growth of human culture and thinking, leading to an increase in their knowledge and skills in morality, etiquette, history, art, literature, technology, cultural heritage, customs, religious beliefs. Such philosophical thinking, combined with humanism, democratic principles, and national ideology, prevents corruption, which is a negative evil, even in the face of tragedy and financial hardship, but serves to take a bold step towards a brighter future to build a just life. does. The task of combating corruption is objectively defined as a form of organizing their own society in parallel with the governance of existing states in the world. Some functions of the state, such as defense, national security, and the maintenance (protection) of public order, are traditional because the need to implement them has served as the main reason for the emergence of the state as a historical category. To this day, they remain a hallmark of modern statehood.

One of these trends is corruption in the state apparatus. It is widely believed that largescale, systemic corruption is a property of transition and underdeveloped countries. Indeed, countries with developed market economies and democratic institutions have lower levels of corruption, and they have lower or higher levels of internal corruption, which is a clear indication of the fragmentation of state power. The initiative of state and civil society institutions to combat corruption in public bodies should focus not only on the state and other institutions of civil society but also on civic activism of the population. In this regard, the head of state said that "it should be noted that concrete measures have been taken to prevent and combat corruption, which is a serious threat to the development of the state and society, the people's confidence injustice." [13] A distinctive feature of modern society is the alienation between the state and the citizens living in it, as well as the lack of real interaction between this society and the institutions of civil society.

However, no country today can consider itself "insured" against corruption. The world is globalizing and therefore corruption has become a global problem rather than a problem of individual countries, and this trend is increasingly recognized. Human development has led to a sharp increase in the risk of corruption for the whole world. But progress can also serve to create a system of protection against the adverse events and threats that cause it. The new reality forces us to reconsider the means by which society can counter the threat of corruption.

Corruption and its manifestations are on the rise around the world. Therefore, it is becoming more and more natural for any state to pursue a permanent anti-corruption policy. Only this strategy seems to be the only effective one in the current context. However, it is not opposed to the application of the rule of law by the state against corruption. 
In particular, in conducting an anti-corruption policy, the state and society should see the weaknesses of the police, oversight, and judicial mechanisms and correct them, and most importantly, minimize corruption in the jurisdiction itself.If until now the function of combating crime (more broadly, the protection of law and order) included the fight against corruption, today's anti-corruption policy should become an independent task of the state. This is necessary both in countries with low levels of corruption and in countries in transit countries that have been implementing economic reforms after years of lack of private property rights and a competitive environment.

For clarity, we compare the function of the anti-corruption policy with the function of defense. The latter is very expensive, but in the world you can trust a few states that are not part of the defense in their main functions. If you defend in the fight against corruption usually from this position, it may seem that only the inertia of traditions may require the preservation of this function, because the war of conquest has become the rule of international life. Traditionally, even small states are not in the habit of spending large sums of money to maintain and permanently arm their armies. The natural sense of self-preservation (states, more precisely, societies can also have feelings and instincts) encourages the state to always be ready for one of its primary means of reversing potential danger. The anti-corruption function should become a kind of natural state.

Based on the above considerations, we believe that it is expedient for the state to take permanent measures in the fight against corruption.

In our view, ongoing anti-corruption measures include:

- Development of an anti-corruption program for a certain period, ie the creation of a document containing the main policy directions for a certain period;

- Development of anti-corruption plans for a certain period, ie the creation of documents defining and compiling an anti-corruption program;

- Monitoring the implementation of anti-corruption programs and plans, making the necessary amendments to them and creating a system for assessing the level of their implementation;

- Radical reform of the activities of specialized anti-corruption bodies;

- The activities of regulatory authorities (parliamentary oversight and audit commissions, etc.);

- Continuous monitoring of the state of corruption (from a territorial, sectoral and functional point of view), including through statistical, sociological and other methods;

- Strengthening the system of anti-corruption education and training.

Apparently, this is a system of measures that is universal for different countries.

Hence, the directions of the state anti-corruption policy should include the following.

- Introduction of amendments and additions to the laws;

- Balanced control and balance between the main institutions of power, strengthening the system of mutual restraint;

- Regulation of the system, structure, and functions of executive bodies;

- Change the principles of control over the civil service (primarily civil) and the property status of government officials;

- Creation of conditions for effective control over the distribution and expenditure of budget funds; 
- Strengthening the judiciary;

- Improving the law enforcement system and police (special services);

- Coordination of anti-corruption policy, etc.

The directions of anti-corruption policy should be supplemented and changed as a result of an in-depth study of new knowledge about the nature of corruption at different levels industrial, regional, functional, as well as the fight against corruption after a detailed study of the causes of corruption.

The features of Uzbekistan's anti-corruption policy can be seen in the following. The analysis shows that a number of international legal instruments aimed at ensuring the fight against the threat of corruption, which hinders the development of society in the world, including:

- International Code of Ethics for Public Officials (New York, December 12, 1996);

- Convention on Criminal Liability for Corruption (Strasbourg, January 27, 1999);

- Convention on Civil Liability for Corruption (Strasbourg, November 4, 1999) and the Additional Protocol to the Convention (Strasbourg, May 15, 2003);

- The United Nations Convention against Corruption (October 31, 2003) and others.

\section{CONCLUSION}

On the basis of international law and national legislation, organizational and legal mechanisms in the field of combating corruption have been created in our country.

First, the Budget Code, which is aimed at strengthening the legal framework for the prevention of corruption, "On crime prevention", "On social partnership", "On transparency of public administration", "On operational search activities", "On e-government" and the Law on Parliamentary Oversight.

Second, the adoption of the Law of the Republic of Uzbekistan "On Combating Corruption" on January 3, 2017 in order to effectively combat corruption - allowed to create an integrated system that combines the strength and capabilities of government agencies and civil society institutions in combating corruption.

According to Article 5 of this law, the main directions of state policy in the field of combating corruption are:

- Raising the legal awareness and legal culture of the population, the formation of an intolerant attitude to corruption in society;

- Iimplementation of measures to prevent corruption in all spheres of state and public life;

- Timely detection of corruption offenses, their elimination, elimination of their consequences, the causes and conditions that allow them, ensuring the principle of inevitability of liability.

In general, the work done in Uzbekistan in recent years to combat corruption can be positively assessed. At the same time, the issue of recognizing that the main force is the state and creating a transparent environment in all areas is on the agenda. At the same time, we must not forget that we are responsible for the implementation of the decisions and decrees of the head of our state. 


\section{REFERENCES}

[1] Mirziyoev Sh.M. The consent of our people is the highest value given to our activities. -T.: Uzbekistan, Volume 2, 2018. Pages 23-24.

[2] Mirziyoyev Sh. We will resolutely continue our path of national development and raise it to a new level. - T.: Uzbekistan, Volume 1, 2017. Page 89.

[3] Karimov I.A. It is our most urgent task today to take the reforms we have started to a new level, not limited to the achievements we have made. -T.: Uzbekistan, Volume 23, 2015. Pages 267-268.

[4] Yaxshilikov J.Ya., Muhammadiev N.E. National Idea: Development Strategy of Uzbekistan. Textbook. Cholpon NNMIU, Tashkent, 2018. Pages 466-467.

[5] Mirziyoev Sh.M. The consent of our people is the highest value given to our activities., -T.: Uzbekistan, Volume 2, 2018. Page 90.

[6] Constitution of the Republic of Uzbekistan. -T.: Uzbekistan, 2000, p.11.

[7] Karimov I.A. May we have a free and prosperous Motherland. Volume 2 -T .: Uzbekistan, 1996, p.98.

[8] Mamashokirov S., Togaev Sh. Ideological issues of building a free and prosperous life. -T.: Spirituality, 2007. p.20.

[9] Musaev F. Philosophical and legal bases of building a democratic state. -T.: Uzbekistan, 2007. 222 pages.

[10] Xo'janova T.J. Ideological prevention is a factor of ideological protection of the younger generation (socio-philosophical analysis). National Society of Philosophers of Uzbekistan Publishing House, Tashkent, 2019. 125 pages.

[11] Mirziyoyev Sh. We will resolutely continue our path of national development and raise it to a new level. - T.: Uzbekistan, Volume 1, 2017. page 500

[12] Normatov K., Fayziev S. Some issues of educating young people in the spirit of national ideas and ideology and the fight against terrorism. // The role of national ideas and ideology in the development of philosophical and legal sciences. -T.: 2008, Philosophy and Law Publishing. Page 77

[13] Mirziyoev Sh.M. The work of a nation with a great intention will also be great, its life will be bright and its future will be prosperous. -Tashkent: Volume 3, Uzbekistan, 2019. p.65. 